\section{AUTHORS:}

Maria H. Hamunyela ${ }^{1,2}$

Emmanuel Nepolo ${ }^{3}$ iD

Mohammad N. Emmambux ${ }^{4}$ iD

\section{AFFILIATIONS:}

1Department of Biological

Sciences, University of Namibia,

Windhoek, Namibia

2Department of Food Science and

Technology, University of Namibia,

Windhoek, Namibia

${ }^{3}$ Department of Biochemistry and

Microbiology, University of Namibia,

Windhoek, Namibia

${ }^{4}$ Department of Consumer and Food

Sciences, University of Pretoria,

Pretoria, South Africa

CORRESPONDENCE TO:

Mohammad Emmambux

EMAIL:

naushad.emmambux@up.ac.za

\section{DATES:}

Received: 07 Aug. 2019

Revised: 04 Jan. 2020

Accepted: 24 Jan. 2020

Published: 27 May 2020

\section{HOW TO CITE:}

Hamunyela MH, Nepolo E,

Emmambux MN. Proximate and

starch composition of marama

(Tylosema esculentum) storage roots

during an annual growth period. S Afr

J Sci. 2020;116(5/6), Art. \#6782,

6 pages. https://doi.org/10.17159/

sajs.2020/6782

\section{ARTICLE INCLUDES:}

囚 Peer review

$\square$ Supplementary material

\section{DATA AVAILABILITY:}

$\square$ Open data set

$\square$ All data included

凶 On request from author(s)

$\square$ Not available

$\square$ Not applicable

EDITORS:

Teresa Coutinho iD

Salmina Mokgehle iD

\section{KEYWORDS:}

marama root, marama root starch, proximate analysis, starch granules, total starch, high amylose starch

\section{FUNDING:}

National Research Foundation (South Africa)

\title{
Proximate and starch composition of marama (Tylosema esculentum) storage roots during an annual growth period
}

\begin{abstract}
The aim of this study was to determine the most suitable time for harvesting marama (Tylosema esculentum) root as an alternative source of novel starch by evaluating the quality of marama root and its starch during growth periods of 12 months. The effects of time on the proximate analysis of marama roots as well as the thermal properties, size and physicochemical properties of the starch were also investigated. Marama was planted in September and total starch of marama roots on both as is and dry bases increased significantly $(p<0.05)$ from $24 \mathrm{~g} / \mathrm{kg}$ to $115 \mathrm{~g} / \mathrm{kg}$ and $259 \mathrm{~g} / \mathrm{kg}$ to $601 \mathrm{~g} / \mathrm{kg}$, respectively, from 2 to 12 months after planting. Amylose content significantly $(p<0.05)$ decreased from about $50.7 \%$ to $21.4 \%$ of the starch for the same time period. The size of marama root starch granules significantly $(p<0.05)$ increased from $8.6 \mu \mathrm{m}$ to $15.1 \mu \mathrm{m}$. The marama root harvested after 2 months had the highest crude protein content $(33.6 \%)$. In terms of thermal properties, the peak temperature decreased significantly with time (ranging from $93.0^{\circ} \mathrm{C}$ to $73.4^{\circ} \mathrm{C}$ ), while the $\Delta \mathrm{H}$ increased significantly with time. The findings indicate that marama should be planted early in summer and harvested between 4 and 8 months for optimal starch before winter.

\section{Significance:}

Proximate and starch characteristics of marama storage roots differ significantly with time of harvest. This suggests that desired functional properties can be achieved by controlling growth time. The marama root harvested at 4 months is highly nutritious, it has high protein content, starch that is high in amylose and is suitable for consumption as a fresh root vegetable in arid to semi-arid regions where few conventional crops are able to survive. Marama root is a climate smart crop and it could potentially contribute to food security in arid regions. The results obtained in this study suggest that the optimum time for harvesting marama as a root vegetable is at 4 months while the optimum time for harvesting marama for its starch is at 8 months. Younger roots have higher amylose, and hence higher gelatinisation temperatures, and therefore may be more suitable to be used as a coating during frying.
\end{abstract}

\section{Introduction}

Starch is the most common carbon reserve stored in plants; it is of great significance for both food and non-food industrial uses. ${ }^{1}$ About 75 million tonnes of starch is produced for worldwide industrial applications ${ }^{2}$ and about $54 \%$ of the starch produced globally is utilised for food applications ${ }^{3}$. Starch is also a major source of energy in the human diet. It accounts for approximately $50 \%$ of calorie intake in developed countries and $90 \%$ of calorie intake in developing countries. ${ }^{4}$ Current sources of commercially available starch are a restricted range of crops, the most important being maize, potato, wheat and cassava with smaller amounts from rice, sorghum, sweet potato, arrowroot, sago and mung beans. ${ }^{5}$ The main crops in sub-Saharan Africa are maize, rice, pearl millet, sorghum, cassava, yam and sweet potatoes. ${ }^{6}$ However, there is no commercialised starch from indigenous staple crops in Namibia and they are underutilised. The underutilised crops may provide starches or flours with novel physicochemical properties.

Marama is a wild-growing and drought-tolerant legume, native to the arid and semi-arid regions of southern Africa. It produces protein and oil rich seeds and is a storage root used as food. ${ }^{7}$ In Namibia it grows wild mainly in the Omaheke and Otjizondjupa regions, while it grows in the Limpopo, Gauteng and Northern Cape Provinces of South Africa. ${ }^{8}$ Marama is a storage root bearing plant that is indigenous to the Kalahari sandy region, ${ }^{9}$ and could prove to be a starch alternative due to its ability to survive aridity. Plant roots such as cassava and tubers such as potato are rich in starch and they are among the sources of starch for consumption or industrial use..$^{10}$ According to Huang et al. ${ }^{11}$, roots and tubers contain $70-80 \%$ water, $16-24 \%$ starch and trace amounts of protein and lipids. The dry matter of roots and tubers mainly consists of starch, which accounts for approximately $70 \%$ of the total solids, thus making it the major component. ${ }^{12}$ Due to their high starch content, root and tuber crops are thus important staple foods and are also used as ingredients in processed foods across the world. ${ }^{12}$ Previous reports show that starch morphology, starch composition and the proximate composition of roots and tuber crops such as yam, cassava, potato and sweet potato are affected by the time of harvest. It has been shown that starch content and starch granule size increase with crop maturity in all roots and tubers while starch granule shapes remain the same. ${ }^{13-16}$

Both the seeds and the storage root of marama are used for consumption by local people. ${ }^{8}$ The seeds are roasted and eaten as a snack ${ }^{17}$ while the root is boiled or roasted for consumption as a vegetable ${ }^{18}$. Marama seeds and the storage root have a high nutrient value, and are rich in protein, oil and starch. Marama is a potential crop for arid areas where few conventional crops can survive because of its ability to grow naturally in the poor soil and dry conditions of Namibia. Marama has potential to be a climate change friendly food crop for southern Africa. It thrives in arid conditions due to the plant's ability to employ several mechanisms to grow and survive in drought-stricken environments. Marama is able to withstand temperatures of up to $50^{\circ} \mathrm{C}$, it is also able to withstand limited water by reduced surface area of the leaves to reduce water loss and it can survive by making use of water stored in 
the tuberous root. It also has a tap root that penetrates deep below the surface to allow access to subsoil water. ${ }^{19}$ The starch accumulation and physicochemical properties of the marama root have not been studied extensively. Marama root starch reportedly has a high viscosity and therefore has potential as a thickener in food products. ${ }^{20}$ Thus, research and product development are needed to exploit marama root starch. The objective of this study was therefore to investigate the influence of time on the proximate analysis of marama roots and the influence of time on the starch granule size, thermal and physicochemical properties of the marama root starch. The published paper by Adeboye and Emmambux ${ }^{20}$ concentrated on the physicochemical, morphological, thermal and pasting properties of marama storage root starch but did not study the effects of harvest time on the marama root starch. The marama roots used in their study were harvested 6 months after planting. We report the changes in the physicochemical properties of starch from marama roots over a period of 12 months. In addition, we provide the first report on changes during tuberous root development. The main aim of this study was to determine the most suitable time for harvesting by evaluating the quality of marama root and its starch at different times during a 12-month period.

\section{Materials and methods}

\section{Samples}

Marama plants were grown in a greenhouse on the University of Namibia NEUDAM campus, which is located at $22^{\circ} 30.105^{\prime \prime} \mathrm{S}$ and $017^{\circ} 20.824^{\prime \prime} \mathrm{E}$, $30 \mathrm{~km}$ east of Windhoek, the capital city of Namibia. Marama seeds were collected from an experimental field in Omitara which is located in the Omaheke region in the central eastern part of Namibia. Marama seeds $(n=144)$ were planted in a greenhouse; each seed was planted in a 20-L pot. Seeds were planted in September when the daily average temperature was $28^{\circ} \mathrm{C}$ and grown for 12 months. Roots were randomly selected at different stages of development for analysis. The roots were harvested in November, January, May and finally in September, equivalent to 2, 4, 8 and 12 months after planting, respectively. The analyses were done in harvested months. Some of the analyses were done on fresh roots while some were performed on freeze-dried roots. The roots were freeze dried and ground into flour for proximate, total starch content, amylose content and thermal properties analyses.

\section{Analyses}

\section{Size determination}

The fresh mass of the roots was determined using a weighing balance, while the diameter of roots was determined using a vernier calliper. The diameter was measured in the middle longitudinal section of the marama root. The measurements were done at 2, 4, 8 and 12 months after planting.

\section{Determination of total soluble solids}

Freeze-dried marama root was mixed with distilled water $(10 \%$ slurry), filtered and the total soluble solids were measured using a digital refractometer. The total soluble solids were expressed as a Brix percentage. The refractometer was calibrated with distilled water before taking the measurements.

\section{Proximate composition}

Moisture, ash and crude fibre of freeze-dried marama roots were determined using Association of Official Analytical Chemists (AOAC) methods 925.45B, 942.05 and 962.09 , respectively. ${ }^{21}$ Crude protein (Nx-6.25) was determined by the Dumas method, using the Leco CHN 628 series nitrogen combustion system, which is an AOAC method (990.03). ${ }^{22}$

\section{Total starch content}

The Megazyme total starch assay kit (K-TSTA 07/11) (Megazyme International, Bray, Ireland) was used to determine the percentage composition of total starch in freeze-dried marama roots as described by McCleary et al..$^{23}$ Thermostable $\alpha$-amylase and amyloglucosidase enzymes were used to enzymatically hydrolyse starch to glucose and the glucose was quantified using glucose oxidase-peroxidase reaction.
The absorbance for each sample was read at $510 \mathrm{~nm}$ against the reagent blank using a spectrophotometer.

\section{Amylose:amylopectin ratio}

Megazyme amylose:amylopectin assay kit (K-AMYL 07/11) (Megazyme International Bray, Ireland) was used to determine the amylose:amylopectin ratio of freeze-dried marama roots as described by Gibson et al. ${ }^{24}$ who used a modification of a procedure described by Yun and Matheson ${ }^{25}$. The amylose was determined by the precipitation of amylopectin with lectin concanavalin-A protein; amylose was then enzymatically hydrolysed to glucose and quantified using glucose oxidase-peroxidase. The absorbance for each sample was read at $510 \mathrm{~nm}$ against the reagent blank using a spectrophotometer.

\section{Determination of thermal properties}

Thermal properties of ground freeze-dried marama root were determined using the method described by Wokadala et al. ${ }^{26}$ Thermal properties were analysed using a high-pressure differential scanning calorimetry system with STARe software (HPDSC-827, Mettler Toledo, Greifensee, Switzerland). A mass of $10 \mathrm{mg}$ (dry weight basis) of freeze-dried marama root flour was dissolved in $30 \mathrm{mg}$ distilled water and allowed to equilibrate for at least $2 \mathrm{~h}$ at room temperature. Scanning was done at temperatures from $40{ }^{\circ} \mathrm{C}$ to $125^{\circ} \mathrm{C}$ at a rate of $10^{\circ} \mathrm{C} / \mathrm{min}$. Indium $\left(\mathrm{Tp}=156.61^{\circ} \mathrm{C}\right.$, $28.45 \mathrm{~J} / \mathrm{g}$ ) was used as a standard to calibrate the differential scanning calorimetry system and an empty pan was used as a blank reference.

\section{Root microstructure}

A protocol was developed using fixing and staining procedures described by Ruzin ${ }^{27}$. The storage root (2-cm slices) was fixed in formalin-acetic acid and then dehydrated in an ethanol series, wax infiltrated and embedded. Cross sections of $10-\mu \mathrm{m}$ thickness were prepared and mounted on slides before staining with periodic acid-Schiff, and counter staining with amido black 10B. Periodic acid-Schiff stains starch a bright fuchsia and amido black stains proteins in the cell walls a deep blue colour. Slides were viewed using a Zeiss Axio Imager 2 microscope (Oberkochen, Germany) and digital images were taken using an Axiocam ERC5S camera to determine starch accumulation, granule size and shape of the starch.

\section{Statistical analyses}

Statistical analyses were conducted using the SPSS 21 statistical package (Chicago, IL, USA). The data were subjected to a one-way analysis of variance (ANOVA); $p \leq 0.05$ was considered significant. Duncan's multiple range test was used to further compare the means to determine which of the means is significantly different. Data were presented as means \pm standard deviation. The independent variable in this study is time, while the dependent variables are the root and starch characteristics.

\section{Results and discussion \\ Morphology and proximate composition}

The marama root morphology and proximate composition of marama roots harvested at different times are presented in Table 1. As expected, the fresh mass and diameter of the marama root significantly increased $(p<0.05)$ with time up until 8 months after planting. The root attained a weight of up to $420 \mathrm{~g}$ in 8 months. Bousquet ${ }^{28}$ reported that the marama storage root can reach a weight of up to $12 \mathrm{~kg}$ within a few unspecified years. However, roots can grow larger and a root weighing $277 \mathrm{~kg}$ has been found in Botswana. ${ }^{29}$ The 8-month root weighed more than the 12-month root did - a difference which may be related to the winter months (June, July and August). Marama leaves and vines are lost during winter and sprout back after winter. Consequently, the plants could not produce photosynthate and thus the 12-month root weighed less than the 8-month root, although it was older. Because 12-month roots were harvested right after winter, it is suspected that the plants would then have had to rely on their reserves to survive winter.

The average moisture content of the fresh marama storage root significantly $(p<0.05)$ decreased from $91 \%$ to $81 \%$ as root development progressed. The older roots appeared to be more fibrous then the younger roots, but the youngest roots appeared to consist mostly of 
Table 1: Morphology and proximate analysis results of marama storage root

\begin{tabular}{|c|c|c|c|c|c|c|c|}
\hline \multirow{2}{*}{ Harvesting month } & \multirow{2}{*}{ Moisture (\%) } & \multirow{2}{*}{ Mass (g) } & \multirow{2}{*}{ Diameter (cm) } & \multicolumn{4}{|c|}{ Composition (\% dry weight) } \\
\hline & & & & Ash & Crude protein & Total soluble solids & Crude fibre \\
\hline 2 & $90.9^{\mathrm{a}} \pm 1.36$ & $14.6^{\mathrm{a}} \pm 3.38$ & $1.4^{\mathrm{a}} \pm 0.19$ & $6.3^{a} \pm 0.12$ & $33.6^{a} \pm 0.06$ & $6.4^{a} \pm 0.0$ & $7.2^{\mathrm{a}} \pm 0.26$ \\
\hline 4 & $89.4^{\mathrm{a}} \pm 0.51$ & $38.9^{\mathrm{a}} \pm 4.70$ & $2.7^{b} \pm 0.34$ & $5.9^{a} \pm 0.34$ & $14.0^{b} \pm 0.06$ & $5.8^{b} \pm 0.06$ & $6.7^{b} \pm 0.17$ \\
\hline 8 & $86.6^{b} \pm 0.10$ & $420.4^{b} \pm 62.61$ & $6.5^{c} \pm 1.36$ & $4.3^{b} \pm 0.25$ & $3.3^{c} \pm 0.06$ & $3.7^{c} \pm 0.11$ & $6.8^{\mathrm{b}} \pm 0.18$ \\
\hline 12 & $80.8^{c} \pm 1.42$ & $326.4^{\mathrm{c}} \pm 37.07$ & $5.7^{c} \pm 0.30$ & $3.1^{c} \pm 0.06$ & $2.7^{\mathrm{d}} \pm 0.05$ & $2.3^{d} \pm 0.10$ & $5.6^{c} \pm 0.13$ \\
\hline
\end{tabular}

Mean values followed by a different superscript letter in the same column are significantly different $(\mathrm{p}<0.05)$.

water. Similarly, young cassava roots contain less starch than older roots which also have a higher fibre content. ${ }^{13}$ The ash content of the ground marama storage root flour also significantly $(p<0.05)$ decreased with time from about $6.3 \%$ to $3.1 \%$ from month 2 to 12 . Ash content of yam tubers was also reported to be higher in tubers harvested during the early stages of growth than at later stages. ${ }^{11}$

The same trend was observed for the total soluble solids that significantly $(p<0.05)$ decreased with time from $6.4 \%$ to $2.3 \%$ from month 2 to 12 . Glucose is the first precursor of starch biosynthesis in the roots and tubers. Glucose and sucrose are soluble sugars; soluble sugars decreased significantly during the development of potato tubers. ${ }^{14}$ There was a general increase in starch and a decrease in sugars during potato tuber development. Maturing of tubers is hence marked by the decline in sugars which is associated with an increase in starch. ${ }^{14}$ A high sugar load correlated with the onset of starch accumulation at the beginning of tuber development and starch content increased rapidly thereafter. ${ }^{30}$ The decrease in total soluble solids in this study is probably due to a decrease in total soluble sugars (during starch biosynthesis and accumulation); further determinations are, however, necessary.

The crude protein content significantly $(p<0.05)$ reduced from $33.6 \%$ to $2.7 \%$ from month 2 to 12 . Similarly, there was a decrease in protein content during potato tuber development. ${ }^{31} \mathrm{~A}$ reduction of protein in this study is probably an indication of a decrease in protein synthesis. Potato tuber maturity is characterised by a progressive inactivation of the protein synthesis system. ${ }^{31}$ In general, marama storage root has a high protein content ${ }^{29}$ - higher than that of cassava $(0.95-6.42 \%)$, sweet potato $(3.15 \%)$, taro $(6.28 \%)$ and yam $(10.46 \%){ }^{32,33}$

\section{Starch composition and thermal properties}

The total starch content of the ground marama storage roots (Table 2) significantly increased from $259 \mathrm{~g} / \mathrm{kg}$ to $601 \mathrm{~g} / \mathrm{kg}$ on a dry basis from month 2 to 12. The total starch content (fresh basis) of the marama root increased from $24 \mathrm{~g} / \mathrm{kg}$ to $115 \mathrm{~g} / \mathrm{kg}$ from month 2 to 12 . As expected, both the dry weight basis and fresh basis total starch content of the marama root increased significantly with age $(p<0.05)$. Similarly, a variation in the starch content of potato tubers and cassava roots harvested at different times has been reported, with the highest starch content recorded at 2-3 months for potato tubers. ${ }^{34} \mathrm{~A}$ previous report indicates that the total starch content of cassava roots increased with time until it reached its maximum at the 14th month. ${ }^{16}$ Changes in starch content are indicators of a variety of different plant development processes. ${ }^{35}$ Starch accumulation in roots is determined by a higher starch synthesis enzyme activity, a lower amylase activity (starch degradation) in the roots, the stem transport capacity and the expression of sugar transport genes. The starch synthesis capacity and low starch degradation in roots are strongly associated with a high accumulation of starch in storage roots at late growth stages. ${ }^{36}$

The total starch content on a fresh basis of the marama root for all the root samples was lower than $15 \%$, with the lowest content being $24 \mathrm{~g} / \mathrm{kg}$ and the highest being $115 \mathrm{~g} / \mathrm{kg}$. Nepolo ${ }^{37}$ reported that fresh marama root harvested after 3 months contains $87 \mathrm{~g} / \mathrm{kg}$ total starch content. Their finding is in agreement with results in this study that show that the major component of the fresh marama root is water. In addition, besides water, other non-starch components also affect the total starch content of the marama root. ${ }^{20}$ The starch content in fresh potato tubers reportedly increased from $110 \mathrm{~g} / \mathrm{kg}$ to $135 \mathrm{~g} / \mathrm{kg}$ during potato growth. ${ }^{34}$ The young marama root therefore contains very low starch content and genetic modifications might be required to increase the starch production of the roots. In order to establish marama root starch as an alternative source of starch and increase its economic value, it would be beneficial to increase starch production in marama roots.

Table 2: Starch composition results of marama storage root

\begin{tabular}{c|c|c|c}
\hline \hline \multirow{2}{*}{$\begin{array}{c}\text { Harvesting } \\
\text { month }\end{array}$} & \multicolumn{3}{|c}{ Starch composition } \\
\cline { 2 - 4 } & $\begin{array}{c}\text { Total starch } \\
\text { (g/kg dry weight) }\end{array}$ & $\begin{array}{c}\text { Total starch } \\
(\mathbf{g} / \mathbf{k g} \text { fresh weight) }\end{array}$ & $\begin{array}{c}\text { Amylose content } \\
\text { (\% starch basis) }\end{array}$ \\
\hline \hline 2 & $259^{\mathrm{a}} \pm 0.69$ & $24^{\mathrm{a}} \pm 0.06$ & $50.7^{\mathrm{a}} \pm 0.89$ \\
\hline 4 & $265^{\mathrm{a}} \pm 0.75$ & $28^{\mathrm{b}} \pm 0.08$ & $40.6^{\mathrm{b}} \pm 5.14$ \\
\hline 8 & $490^{\mathrm{b}} \pm 0.83$ & $66^{\mathrm{c}} \pm 0.11$ & $26.6^{\mathrm{c}} \pm 1.33$ \\
\hline 12 & $601^{\mathrm{c}} \pm 1.47$ & $115^{\mathrm{d}} \pm 0.28$ & $21.4^{\mathrm{c}} \pm 0.40$ \\
\hline
\end{tabular}

Mean values followed by a different superscript letter in the same column are significantly different $(\mathrm{p}<0.05 ; \mathrm{n}=3)$.

The amylose content of the marama storage root starch (Table 2) determined by the precipitation of amylopectin significantly decreased with the maturity of the storage root $(p<0.05)$ from $50.7 \%$ to $21.4 \%$ from month 2 to 12. A similar trend was observed for sweet potatoes, whereby the amylose content decreased with harvest time - the values reduced from $23.1 \%$ to $19.7 \% .^{15}$ Similarly, the amylose content of cassava root starch was also highest in the roots harvested early; it varied from $20.6 \%$ to $24.1 \%{ }^{16}$ Noda et al. ${ }^{38}$ also reported that the amylose content of potato starch decreased with time - the starch of the tubers harvested early in the trial had the highest amylose content (21.2\%) compared to the tubers harvested late in the trial (20.2\%). Our findings suggest that the amylose content decreases as the total starch content increases during storage root development, which is an indication of a delay in amylopectin synthesis as compared to amylose. The activity of granule-bound starch synthase, which is responsible for the synthesis of amylose, decreased, while that of soluble starch synthase, which is responsible for the synthesis of amylopectin, increased during the development of potato tubers. ${ }^{13}$ The results suggest that younger roots contain high amylose starch. High amylose starch is highly sought after due to its unique functional properties. The starch in younger roots is higher than any amylose content reported in the literature for root and tuber starches. The roots and tuber starches are reported to have an amylose content ranging from $10 \%$ to $38 \%{ }^{39}$ High amylose starch is considered to be an important source of food with highly resistant starch. High amylose starch could be used as an ingredient in the preparation of novel starch food to improve resistant starch content and hence decrease glycaemic load. ${ }^{40}$ When domesticated, farmers could decide when to harvest depending on the amylose content and thus the functional properties of the starch. The desired functional properties of starch can therefore be achieved by controlling growth time without the need for chemical or physical modifications of the starch for specific applications. ${ }^{34}$ However more analyses and research are recommended to study the mechanism of amylose and amylopectin accumulation in marama root. 
The endothermic peaks of marama root flour samples are presented in Figure 1. The endothermic peaks yielded were probably due to starch gelatinisation and not protein denaturation. It was observed that the onset (To), peak gelatinisation (Tp) and conclusion (Tc) temperatures decreased with harvesting time while enthalpy change $(\Delta \mathrm{H})$ increased significantly $(p<0.05)$. In contradiction, the temperatures of taro root increased with harvesting time, as did $\Delta \mathrm{H} .{ }^{41}$ The To, Tp and Tc for the 4-month roots were $77.4^{\circ} \mathrm{C}, 84.9^{\circ} \mathrm{C}$ and $93.0^{\circ} \mathrm{C}$, respectively, while $\mathrm{To}$, $\mathrm{Tp}$ and Tc for the 12 -month root samples were $74.18^{\circ} \mathrm{C}, 79.1^{\circ} \mathrm{C}$ and $84.6^{\circ} \mathrm{C}$, respectively. The $\Delta \mathrm{H}$ for the 4-, 8- and 12-month root samples were $2.2 \mathrm{~J} / \mathrm{g}, 8.2 \mathrm{~J} / \mathrm{g}$ and $12.3 \mathrm{~J} / \mathrm{g}$, respectively.

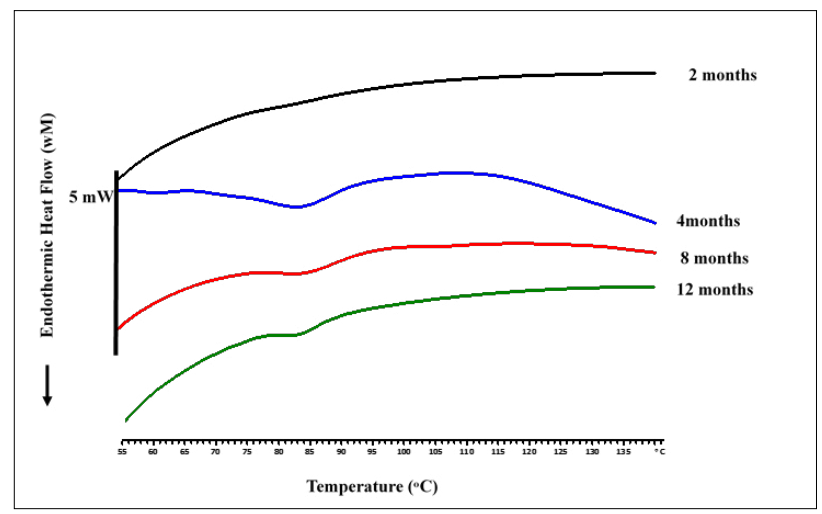

Figure 1: Differential scanning calorimetry curves of marama root harvested at different months (on a dry starch basis).

As expected, time had an effect on the thermal properties of the marama root starch, this finding may be attributed to the difference in the amylose content and starch granule size and also to the difference in other nonstarch components of the ground root flour samples. Thermal stability is a property that is influenced by various factors. No endothermic peak was yielded by the 2-month root flour sample in the temperature range $30-120^{\circ} \mathrm{C}$; this was probably due to low starch content, high concentration of non-starch components and high amylose starch in this root sample. It is difficult to accurately define the gelatinisation temperature of high amylose starch because of the flat endotherm. ${ }^{42}$ High amylose starch has high gelatinisation temperatures; it is fully gelatinised at temperatures higher than $130^{\circ} \mathrm{C} .{ }^{43-45}$

To, Tp and Tc decreased with crop maturity - this finding is positively linked with a decrease in other components of the root, such as protein, total soluble solids, ash content and fibre content. Thus, the younger roots had higher endotherm temperatures than the older roots. The higher endothermic temperatures could be due to the interactions of the starch with other starch components. The study of starch gelatinisation in flour samples is more complex due to the interactions that can occur between starch and other components present. ${ }^{46}$ Starch gelatinisation is delayed by the presence of sugars, because sugars decrease the water activity and interact with the starch chains. ${ }^{47}$ The effect of sugars on the gelatinisation of potato starch has been reported previously. Similarly, there was a decrease in peak temperature in this study as the total soluble solids decreased. The Tp for the gelatinisation of potato starch increased due to the interactions of the sugar with the starch and also the immobilisation of the water molecules. ${ }^{48}$ Moreover, proteins have an effect on the availability of water needed to interact with starch, thereby causing an increase in gelatinisation temperatures. ${ }^{49}$ The proteins form complexes with starch on the starch granule surface, decreasing amylose leaching and affecting water availability. ${ }^{50}$

Furthermore, $\Delta \mathrm{H}$ increased with the maturity of the marama storage roots - this finding is positively linked with a decrease in amylose and an increase in amylopectin from 2 to 12 months, thus the crystallinity of the starch increased with crop maturity. Amylopectin content is a determining factor for starch crystallinity and hence thermal properties. ${ }^{43}$ As the stability of the crystallites increase with crop maturity, $\Delta \mathrm{H}$ also increases. A similar trend was observed in sweet potatoes, whereby $\Delta \mathrm{H}$ was lowest in sweet potatoes harvested earlier. ${ }^{15}$ When amylopectin content increases, $\Delta \mathrm{H}$ also increases, thus normal starch has a lower $\Delta \mathrm{H}$ than waxy starch. Waxy starch displays a higher $\Delta \mathrm{H}$, which reflects the higher percentage of crystallinity of the amylopectin. ${ }^{11}$ However $\Delta H$ is not only a function of the crystallinity but is also determined by a variety of other factors, such as interactions between non-starch components and the starch content of samples.

The powdered marama roots harvested at 4 and 8 months had a higher range (To-Tc) of endothermic peaks compared with powdered marama roots harvested at 12 months. This finding indicates that the thermal stability of the powdered marama roots harvested at 2, 4 and 8 months was higher than the thermal stability of the powdered marama root harvested at 12 months. A higher thermally stable flour will take longer to cook, but may have desirable functional properties in the food industry, such as coating during deep frying.

\section{Root microstructure}

Figure 2 shows cross sections of marama storage roots harvested at different times. All the roots were characterised by parenchyma cells which contained the starch granules. Starch accumulation was observed in all marama roots regardless of age and was reflected by a purple or magenta colour. The periodic acid-Schiff stained the cell walls and the starch granules purple/magenta while the amido black stained the starch granule surface proteins and cell wall proteins a blue colour. The 2-month root had more cells that contained no starch granules than did the other root samples; hence this sample contained a lower total starch content than the other root samples. The periodic acid-Schiff stains insoluble carbohydrates that contain one or two glycol groups. ${ }^{52}$ The marama starch granules are contained in parenchyma cells where they are synthesised in the amyloplasts. The micrographs of the marama storage roots cross sections were similar to those that were prepared by Rouse-Miller et al. ${ }^{53}$ for cassava roots. All micrographs showed purple/magenta-stained starch granules contained in parenchyma cells. The marama starch granules are stained a blue to black colour on the surface by the amido blue, which indicates the presence of surface proteins on the marama starch granules. Starch granules contain a small amount of granule-bound proteins; the granule proteins are found on the surface of the granules and on the interior parts. ${ }^{54}$

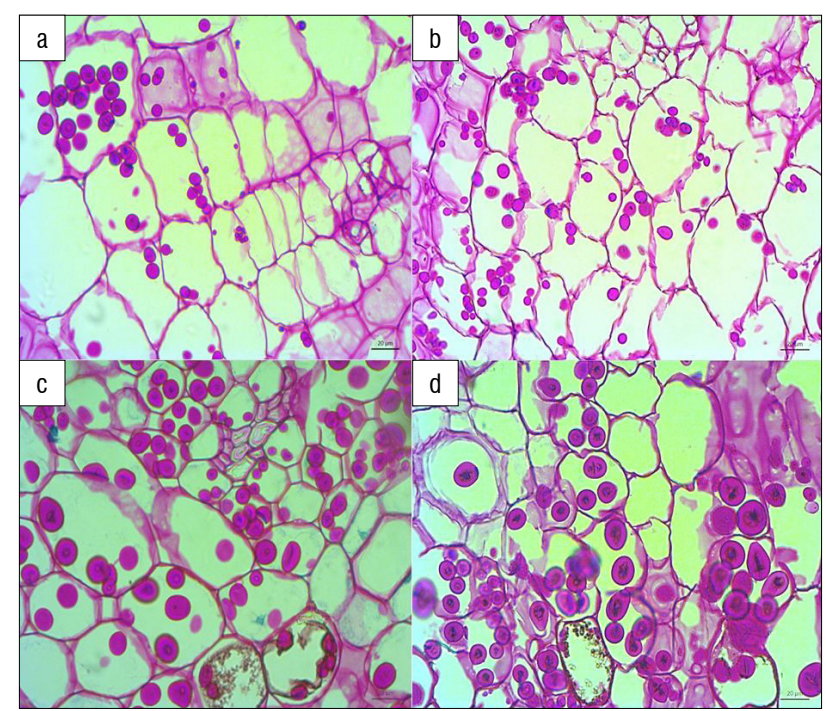

Scale bar $=20 \mu m$

Figure 2: Micrographs of marama root harvested at (a) 2 months, (b) 4 months (cell walls are not intact, probably due to poor fixation of the root), (c) 8 months and (d) 12 months. The starch granules are stained magenta with periodic acid-Schiff, which stains carbohydrates a purple or magenta colour, while amido black stains cell wall proteins and granule proteins blue.

The sizes of the marama root starch granules appeared to be normally distributed (Figure 3). The average starch granule size of the marama root 
starch significantly increased with time $(p<0.05)$. The roots harvested after 2, 4, 8 and 12 months have an average granule size of 8.3, 9.3, 11.9 and $15.1 \mu \mathrm{m}$, respectively. A similar trend was also observed in potato tubers during growth: the average granule size of potato tubers increased from $19.1 \mu \mathrm{m}$ to $21.1 \mu \mathrm{m}$ as potato growth time increased until it reached its highest level and then it decreased. ${ }^{34}$ Similarly, the average granule size of two different varieties of sweet potatoes increased with the stage of development (time), from $8.58 \mu \mathrm{m}$ to 11.0 $\mu \mathrm{m} .{ }^{15}$ Our findings are in agreement with the observations of Noda et $\mathrm{al}^{38}$, who showed that the average starch granule size of potatoes also increased with the stage of development. Previous research shows a positive correlation between potato tuber size and potato starch granule size. ${ }^{34}$ Similarly, an increase in marama root size positively correlated with the marama root starch granule size. There was a very strong positive correlation between marama root size and marama root starch granule size $(r=0.798)$.

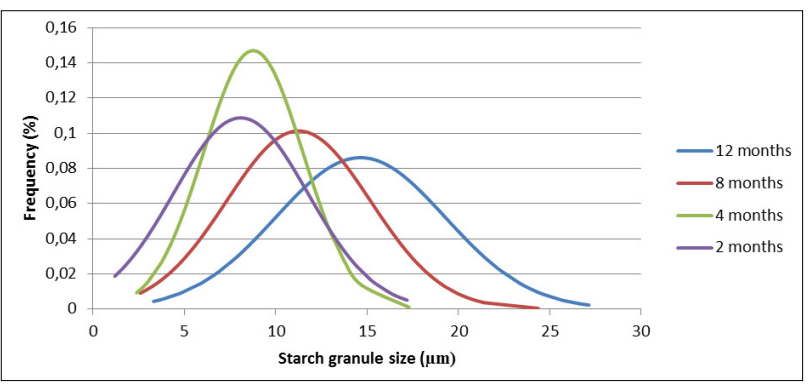

Figure 3: Size distribution curve of marama root starch granules from roots harvested at 2, 4, 8 and 12 months.

The shapes of the marama starch granules are similar in all the marama root samples and time had no effect on the shape of the starch granules. The marama starch granules are spherical, oval or lenticular in shape. This observation is in agreement with that of Adebola and Emmambux ${ }^{20}$ who reported that the shapes of marama starch granules were rounded, oval or lenticular, similar to those of potatoes but smaller in size. However, very few irregular-shaped granules were also observed in this study. Marama starch granules are almost similar in shape to the cassava starch granules, apart from the truncated shape of some of the cassava starch granules. Cassava starch granules were described as round, oval or truncated in shape. ${ }^{55}$

\section{Conclusions}

The chemical composition of marama storage root was affected by the age of the root. Marama root should be harvested for its starch at about 8 months and planting should be undertaken at the beginning of summer for optimal starch. Marama roots can also be harvested at 4 months as a fresh vegetable due to the high nutritional value at this age. Young roots are high in protein and amylose starch. Our findings suggest that marama root can be used as an alternative source of starch and fresh root vegetable. Desired functional properties can be achieved by controlling growth time. The accumulation of starch, starch amylose and amylopectin, and starch molecular structure is different at different growth periods and further research is needed.

\section{Acknowledgements}

We thank the National Research Foundation (South Africa) for funding received for the joint research grant under the South African-Namibian Bilateral Agreement.

\section{Authors' contributions}

M.H.H.: Conceptualisation, methodology, data collection, sample analysis, data analysis, writing - the initial draft, writing - revisions, project management. E.N.: Conceptualisation, student supervision, project management, funding acquisition. M.N.E.: Conceptualisation, writing revisions, student supervision, project leadership, project management, funding acquisition.

\section{References}

1. Geigenberger P. Regulation of sucrose to starch conversion in growing potato tubers. J Exp Bot. 2003;54(382):457-465. https://doi.org/10.1093/jxb/erg074

2. Waterschoot J, Gomand SV, Fierens E, Delcour JA. Production, structure physicochemical and functional properties of maize, cassava, wheat, potato and rice starches. Starch/Stärke. 2015;67:14-29. https://doi.org/10.1002/ star.201300238

3. Omojola M. Tacca starch: A review of its production, physiochemical properties, modification and industrial uses. AJFAND. 2013;13(4):7972-7985

4. Xu J, Kuang Q, Wang K, Zhou S, Wang S, Liu X. Insights into molecular structure and digestion rate of oat starch. Food Chem. 2017;220:25-30. https://doi.org/10.1016/j.foodchem.2016.09.191

5. Wang TL, Bogracheva TY, Hedley CL. Starch: As simple as A, B, C. J Exp Bot 1998;49:481-502. https://doi.org/10.1093/jxb/49.320.481

6. Eriksson D, Akoroda M, Azmach G, Labuschagne M, Mahungu N, Ortiz R. Measuring the impact of plant breeding on sub-Saharan African staple crops. OutlookAgr.2018;47(3):163-180.https://doi.org/10.1177/0030727018800723

7. Travlos IS, Liakopoulos G, Karabourniotis G, Fasseas C, Karamanos AJ. Circadian leaflet movements of Tylosema esculentum (Burch) A. Schreib, and the abolishment of these diurnal movements by potassium deficiency. J Arid Environ. 2008;72:1745-1750. https://doi.org/10.1016/j.jaridenv.2008.03.020

8. Jackson JC, Duodu KG, Holse M, Lima de Faria MD, Jordaan D, Chingwaru W, et al. The morama bean (Tylosema esculentum). A potential crop for southern Africa. Adv Food Nutr Res. 2010;61:187-246. https://doi.org/10.1016/B9780-12-374468-5.00005-2

9. Hartley ML, Tshamekeng E, Thomas SM. Functional heterostyly in Tylosema esculentum (Caesalpinioideae). Ann Bot. 2002;89(1):67-76. https://doi org/10.1093/aob/mcf006

10. Shewry PR. Tuber storage proteins. Ann Bot. 2003;91:755-769. https://doi. org/10.1093/aob/mcg084

11. Huang CC, Lin MC, Wang CCR. Changes in morphological, thermal and pasting properties of yam (Dioscorea alata) starch during growth. Carbohydr Polym. 2006;64:524-531. https://doi.org/10.1016/j.carbpol.2005.11.009

12. Huang CC. Physicochemical, pasting and thermal properties of tuber starches as modified by guar gum and locust bean gum. Int J Food Sci Technol. 2009;44:50-57. https://doi.org/10.1111/j.1365-2621.2007.01634.x

13. Trèche $\mathrm{S}$, Agbor-Egbe T. Biochemical changes occurring during growth and storage of two yam species. Int J Food Sci Nutr. 1996;47(2):93-102. https:// doi.org/10.3109/09637489609012570

14. Lewis CE, Lancaster JE, Meredith P, Walker JRL. Starch metabolism during growth and storage of tubers of two New Zealand potato cultivars. New Zeal J Crop Hort. 1994;22(3):295-304. https://doi.org/10.1080/01140671.199 4.9513838

15. Noda T, Takahata $Y$, Kumamoto TN. Developmental changes in properties of sweet potato starches. Starch/Stärke. 1992;44:405-409. https://doi. org/10.1002/star.19920441102

16. Sriroth K, Santisopasri K, Petchalanuwat C, Kurotjanawong K, Piyachomkwan K, Oates CG. Cassava starch granule structure-function properties: Influence of time and conditions at harvest on four cultivars of cassava starch. Carbohydr Polym. 1999;38:161-170. https://doi.org/10.1016/S0144-8617(98)00117-9

17. Nepolo E, Takundwa M, Chimwamurombe PM, Cullis CA, Kunert K. A review of geographical distribution of marama bean [Tylosema esculentum (Burchell) Schreiber] and genetic diversity in the Namibian germplasm. Afr J Biotechnol. 2009;8(10):2088-2093. https://doi.org/10.5897/AJB09.089

18. Keith ME, Renew A. Notes on some edible wild plants found in the Kalahari. Koedoe. 1975;18:1-12. https://doi.org/10.4102/koedoe.v18i1.911

19. Cullis C, Chimwamurombe P, Barker N, Kunert K, Vorster J. Orphan legumes growing in dry environments: Marama bean as a case study. Front Plant Sci. 2018;9:1-7. https://doi.org/10.3389/fpls.2018.01199

20. Adeboye AS, Emmambux NM. Physicochemical, morphological, thermal and pasting properties of marama (Tylosema esculentum) storage root starch. Starch/Stärke. 2016;68:1-9. https://doi.org/10.1002/star.201600084

21. Williams H. Official Methods of Analysis of AOAC International. 17th edn Gaithersburg: AOAC; 2000. 
22. Latimer GW. Official Methods of Analysis of AOAC International. 20th edn. Gaithersburg: AOAC; 2016.

23. McCleary BV, Solah V, Gibson TS. Quantitative measurement of total starch in cereal flours and products. J Cereal Sci. 1994;20:51-58. https://doi. org/10.1006/jcrs.1994.1044

24. Gibson TS, Solah VA, McCleary BV. A procedure to measure amylose in cereal starches and flours with concanavalin-A. J Cereal Sci. 1997;25:111119. https://doi.org/10.1006/jcrs. 1996.0086

25. Yun SH, Matheson NK. Estimation of amylose content of starches after precipitation of amylopectin by concanavalin-A. Starch/Stärke. 1990;42:302305. https://doi.org/10.1002/star.19900420805

26. Wokadala OC, Ray SS, Emmambux MN. Occurrence of amylose-lipid complexes during maize and teff starch biphasic pasting. Carbohydr Polym. 2012;90:616-622. https://doi.org/10.1016/j.carbpol.2012.05.086

27. Ruzin SE. Plant microtechnique and microscopy. New York: Oxford University Press; 1999

28. Bousquet J. The morama bean of the Kalahari desert as a potential food crop , with a summary of current research in texas the morama bean of the Kalahari desert as a potential food crop, with a summary of current research in Texas. Desert Plants. 1982;3:213-215.

29. National Research Council. Lost crops of Africa: Volume II: Vegetables. Washington DC: The National Academies Press; 2006. https://doi. org/10.17226/11763

30. Turesson H, Carlsson AS, Marttila S, Gustavsson KE, Hofvander P, Olsson $\mathrm{ME}$, et al. Characterization of oil and starch accumulation in tubers of Cyperus esculentus var. sativus (Cyperaceae): A novel model system to study oil reserves in nonseed tissues. Am J Bot. 2010;97(11):1884-1893. https:// doi.org/10.3732/ajb.1000200

31. Cocucci SM, Garlaschi FM, Bianchi E, Marre E. Changes of the protein synthesis system during the maturation of potato tubers. Physiol Plant. 1972;27:220-225. https://doi.org/10.1111/j.1399-3054.1972.tb03604.x

32. Cellabos H, Sanchez T, Chaves AL, Iglesias C, Debouck D, Mafla G, et al. Variation in crude protein content in cassava (Manihot esculenta Crantz) roots. J Food Compos Anal. 2006;19:589-593. https://doi.org/10.1016/j. jfca.2005.11.001

33. Aprianita A, Purwandari U, Watson B, Vasiljevic T. Physico-chemical properties of flours and starches from selected commercial tubers available in Australia. Int Food Res J. 2009;16:507-520.

34. Liu Q, Webera E, Currieb V, Yada R. Physicochemical properties of starches during potato growth. Carbohydr Polym. 2003;51:213-221. https://doi. org/10.1016/S0144-8617(02)00138-8

35. Rodrigo J, Rivas E, Herrero M. Starch determination in plant tissues using a computerized image analysis system. Physiol Plant. 1997;99(1):105-110. https://doi.org/10.1034/j.1399-3054.1997.990115.x

36. Li YZ, Zhao JY, Wu SM, Fan XW, Luo XL, Chen BS. Characters related to higher starch accumulation in cassava storage roots. Sci Rep. 2016;6:1-17. http:// doi.org/10.1038/srep19823

37. Nepolo E. Isolation and characterization of starch, starch biosynthetic genes and protease inhibitors from marama bean (Tylosema esculentum) [dissertation]. Windhoek: University of Namibia; 2014.

38. Noda T, Tsuda S, Mori M. The effect of harvest dates on the starch properties of various potato cultivars. Food Chem. 2004;86:119-125. https://doi. org/10.1016/j.foodchem.2003.09.035
39. Schwall GP, Safford R, Westcott RJ, Jeffcoat R, Tayal A, Shi Y-C. Production of very-high-amylose potato starch by inhibition of SBE A and B. Nat Biotechnol. 2000;18(5):551. https://doi.org/10.1038/75427

40. Zhong Y, Zhu H, Liang W, Li X, Liu L, Zhang X. High-amylose starch as a new ingredient to balance nutrition and texture of food. J Cereal Sci. 2018:81:814. http://doi.org/10.1016/j.jcs.2018.02.009

41. Himeda M, Njintang YN, Gaiani C, Nguimbou RM, Scher J, Facho B, et al. Physicochemical and thermal properties of taro (Colocasia esculenta sp.) powders as affected by state of maturity and drying method. J Food Sci Technol. 2014;51(9):1857-1865. http://doi.org/10.1007/s13197-012-0697-9

42. Tester RF. Influence of growth conditions on barley. Int J Biol Macromol. 1997;21:37-45. https://doi.org/10.1016/S0141-8130(97)00039-1

43. Jane J, Chen YY, Lee LF, McPherson AE, Wong KS, Radosavljevic M, et al Effects of amylopectin branch chain length and amylose content on the gelatinization and pasting properties of starch. Cereal Chem. 1999;76:629637. https://doi.org/10.1094/CCHEM.1999.76.5.629

44. Qin F, Man J, Cai C, Xu B, Gu M, Zhu L, et al. Physicochemical properties of high-amylose rice starches during kernel development. Carbohydr Polym. 2012;88(2):690-698. http://doi.org/10.1016/j.carbpol.2012.01.013

45. Case SE, Capitani T, Whaley JK, Shi YC, Trzasko P, Jeffcoat R. et al. Physical properties and gelation behavior of a low-amylopectin maize starch and other high-amylose maize starches. J Cereal Sci. 27:301-314. https://doi. org/10.1006/jcrs.1997.0164

46. Torres MD, Moreira R, Chenlo F, Morel MH. Effect of water and guar gum content on thermal properties of chestnut flour and its starch. Food Hydrocolloid. 2013;33:192-198. https://doi.org/10.1016/j.foodhyd.2013.03.004

47. Moreira R, Chenlo F, Torres MD. Rheological properties of commercia chestnut flour doughs with different gums. Int J Food Sci Technol. 2011:46:2085-2095. https://doi.org/10.1111/j.1365-2621.2011.02720.x

48. Kohyama K, Nishinari K. Effect of soluble sugars on gelatinization and retrogradation of sweet potato starch. J Agric Food Chem. 1991;39:14061410. https://doi.org/10.1021/jf00008a010

49. Larrosa V, Lorenzo G, Zaritzky NE, Califano AN. Effect of the addition of proteins and hydrocolloids on the water mobility in gluten-free pasta formulations. Water. 2012;4:1-17. https://doi.org/10.14294/water.2012.2

50. Şumnu G, Ndife MK, Bayındırlı L. Effects of sugar, protein and water content on wheat starch gelatinization due to microwave heating. Eur Food Res Technol. 1999;209:68-71. https://doi.org/10.1007/s002170050459

51. Tester RF, Morrison WR. Swelling and gelatinization of cereal starches I: Effects of amylopectin, amylose, and lipids. Cereal Chem. 1990;67(6):551-557.

52. Mosele MM, Hansena ÅS, Hansen M, Schulz A, Martens HJ. Proximate composition, histochemical analysis and microstructural localisation of nutrients in immature and mature seeds of marama bean (Tylosema esculentum)-Anunderutilisedfood legume. FoodChem. 2011;127:1555-1561. https://doi.org/10.1016/j.foodchem.2011.02.017

53. Rouse-Miller J, Bowrin V, Sirju-Charran G, Sutton F. Inverse oriented stem cuttings generate tuberous stems in cassava Manihot esculenta Crantz: An alternative sink site. J Plant Biochem Physiol. 2013;1:4-6. https://doi. org/10.4172/2329-9029.1000117

54. Pérez $S$, Bertoft $E$. The molecular structures of starch components and their contribution to the architecture of starch granules: A comprehensive review. Starch/Stärke. 2010;62:389-420. https://doi.org/10.1002/star.201000013

55. Zhu F. Composition, structure, physicochemical properties, and modifications of cassava starch. Carbohydr Polym. 2015;122:456-480. https://doi. org/10.1016/j.carbpol.2014.10.063 